\title{
Graptolite and conodont biostratigraphy of the upper Telychian-lower Sheinwoodian (Llandovery-Wenlock) strata, Jabalón River section, Corral de Calatrava, central Spain
}

\author{
D. K. LOYDELL*, G. N. SARMIENTO†, P. ŠTORCH‡ \& J. C. GUTIÉRREZ-MARCO†
}

*School of Earth and Environmental Sciences, University of Portsmouth, Burnaby Road, Portsmouth, PO1 3QL, UK †Departamento de Paleontología e Instituto de Geología Económica CSIC-UCM, José Antonio Novais 2, 28040 Madrid, Spain

‡Institute of Geology, Academy of Sciences of the Czech Republic, Rozvojová 135, Praha 6, 16500, Czech Republic

\begin{abstract}
A graptolite biostratigraphy is erected for the upper Telychian (upper crenulata Biozone) to lower Sheinwoodian (riccartonensis or dubius Biozone) strata of the Jabalón River section, Spain. Two unconformities are recognized in the section: one between the lapworthi and murchisoni biozones; the other between the murchisoni and riccartonensis biozones. These unconformities coincide with intervals of lowered eustatic sea-level. Graptolite assemblages include both cosmopolitan taxa and some which have been recorded previously from Morocco and/or other Spanish sections. At some stratigraphical levels Pristiograptus or Euroclimacis species are abundant; Monoclimacis, Streptograptus and Mediograptus species are generally uncommon. Conodonts were examined from the upper spiralis through to lower murchisoni Biozone; the occurrences of Pterospathodus amorphognathoides are consistent with the species' known range elsewhere. Four new graptolite species are described: Euroclimacis jabalonensis, E. hamata, Monoclimacis flexa and Stimulograptus pradoi.
\end{abstract}

Keywords: graptolites, Conodonta, Silurian, biostratigraphy, Central Iberian Zone, Spain.

\section{Introduction}

Recent interest in the Llandovery/Wenlock boundary has prompted detailed examination of sections considered to be stratigraphically complete through this interval. As no unconformities had been recognized in the Jabalón River section near Corral de Calatrava by Štorch et al. (1998), this peri-Gondwanan section was selected for detailed study through its upper Telychianlower Sheinwoodian part. This paper describes the results of this study, focusing upon the graptolite and conodont biostratigraphy of the section.

\section{Locality details and previous work}

The section lies about $4 \mathrm{~km}$ NE of the small town of Corral de Calatrava, Ciudad Real Province, central Spain, above the southern bank of the Jabalón River (Fig. 1b). Tectonostratigraphically, the section lies within the Central Iberian Zone of the Iberian Massif (see Robardet \& Gutiérrez-Marco, 2002, fig. 5.1, locality 22). Black, graptolitic Telychian-Homerian strata of the Guadarranquejo Formation overlie the pale quartzose sandstones of the Criadero Quartzite. Exposure is excellent (individual beds can be followed for several tens of metres), although the section is cut by numerous small faults with curving traces.

\footnotetext{
*Author for correspondence: david.loydell@port.ac.uk
}

The first record of Silurian graptolites from the Corral de Calatrava area was from the Puente Morena exposures in the Jabalón river valley, $\sim 6 \mathrm{~km}$ NE of the town (Prado, Verneuil \& Barrande 1855, p. 1015) (Fig. 1a), later confirmed by Cortázar (1880, p. 23), Machens (E. Machens, unpub. Dissertation, Univ. Münster, 1954, p. 78), Gutiérrez-Marco (in Portero García et al. 1988, p. 25) and A. Kappes (unpub. Diplomarbeit, Univ. Würzburg, 1991, locality G2).

A log of the Upper Ordovician-Llandovery strata was provided by García Palacios, Gutiérrez-Marco \& Herranz Araújo (1996, fig. 1) from a section located $3.5 \mathrm{~km}$ north of Corral de Calatrava, on the northern bank of the Jabalón River, $700 \mathrm{~m}$ upstream from its confluence with the Guadiana River (Fig. 1c).

The Silurian section described herein is located halfway between those described above (Fig. 1b); it was briefly mentioned by Kappes (unpub. Diplomarbeit, Univ. Würzburg, 1991) and described in some detail as the Jabalón river section by Š torch et al. (1998, fig. 3), who provided a complete log through the Telychian-Homerian strata. Š torch (1998) described several Telychian graptolites from Spain, including four from the Jabalón River section from the lower part of the stratigraphical interval discussed herein: Euroclimacis iberica Štorch, 'Monograptus' curvus Manck, Oktavites falx (Suess) and Stimulograptus splendens Storch. The section was visited by the Subcommission on Silurian Stratigraphy in June, 1998 (for which Štorch et al. 1998 was the field 


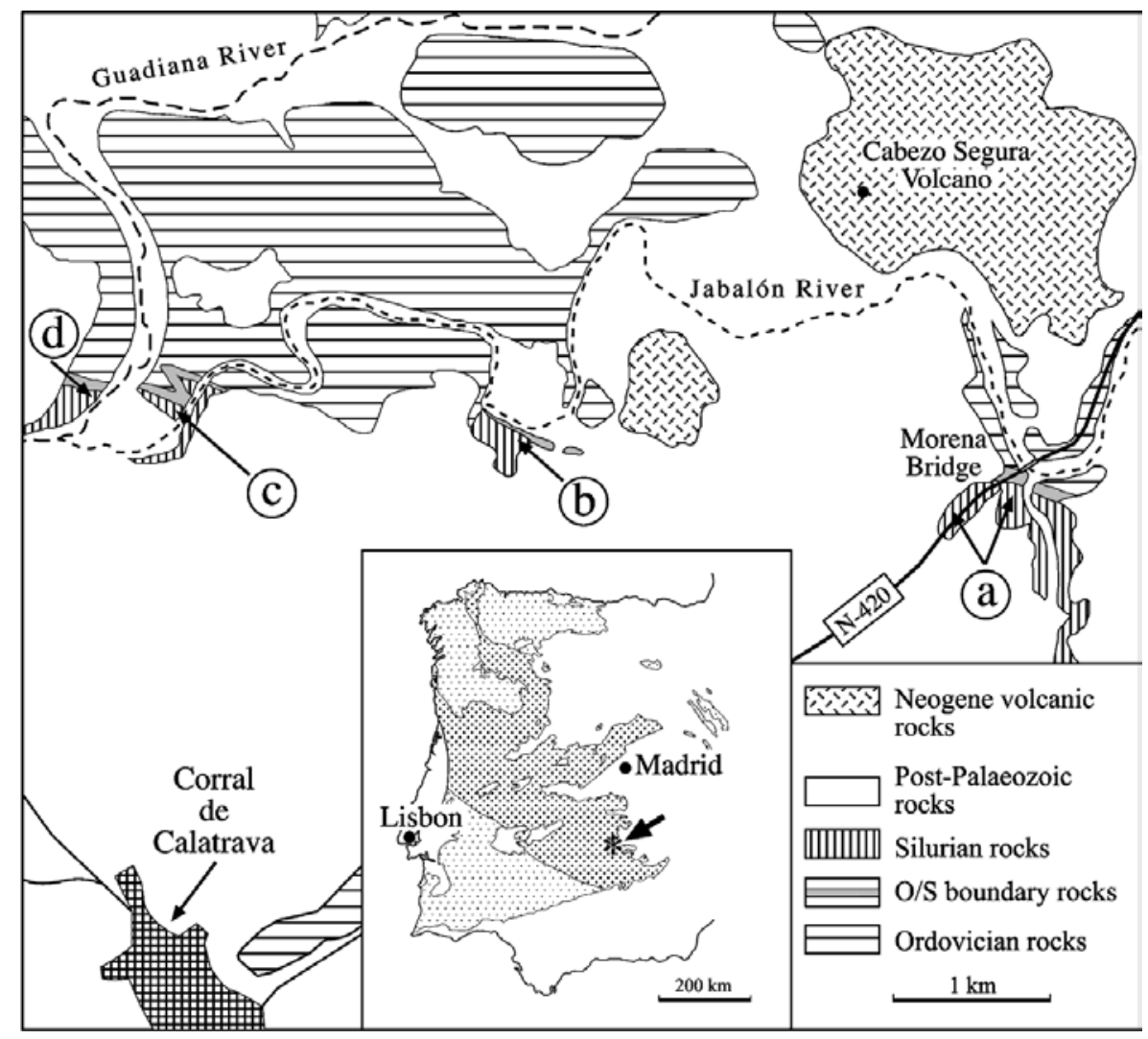

Figure 1. Silurian graptolite localities in the Corral de Calatrava area: (a) Puente Morena outcrops (Prado, Verneuil \& Barrande, 1855 et seq.); (b) Jabalón River section, southern bank, described herein (A. Kappes, unpub. Diplomarbeit, Univ. Würzburg, 1991; Štorch et al. 1998 et seq.); (c) Jabalón River, northern bank (García Palacios, Gutiérrez-Marco \& Herranz Araújo, 1996); (d) Guadiana River section (unpublished locality with poorly preserved graptolites). The geology has been modified from the maps of Portero García et al. (1988) and Kappes (unpub. Diplomarbeit, Univ. Würzburg, 1991). Inset map of the Iberian Peninsula shows location of the studied area within the Iberian Massif (stippled) and its Central Iberian Zone (dense stippling).

guide). García Palacios \& Rábano (1996) described a Telychian trilobite from the CO-12 horizon (Fig. 2) and Sarmiento \& García Palacios (1996) recorded conodont-graptolite co-occurrences in the Telychianlower Sheinwoodian part of the section.

\section{Methods}

The graptolites and conodonts forming the basis of this paper were collected in June 1999. The section was measured from marker levels painted onto the section by Š torch et al. (1998; shown on Fig. 2 as CO12, etc.); shelly horizons (e.g. Fig. 3b, c) and thin micaceous siltstones also provided useful marker beds. Sample thickness was $0.2 \mathrm{~m}$; finer sampling was undertaken around the Llandovery/Wenlock boundary, measuring up from CO15. Levels CO15 and CO16/17 are on opposite sides of a small fault (with a lateral displacement of $\sim 0.4 \mathrm{~m}$ ); correlation across the fault was achieved using the shell bed at $\mathrm{CO} 15+1.2 \mathrm{~m}$ and CO16/17-0.3 m (Fig. 3c). Graptolites are extremely abundant; shelly fossils, including bivalves, eurypterids, phyllocarids, cornulitids, brachiopods, trilobites, orthocones and crinoid columnals, also occur in varying abundances.
The number of graptolites examined from each sample ranged from hundreds to many thousands; thus those species represented by one to three specimens in a collection were indeed 'rare' in our collections. All of the graptolites are preserved flattened, many with a white clay mineral coating the graptolite periderm (Fig. 3a).

Some of the conodonts were collected in the field, by visual hand lens scanning of slabs; many others were found subsequently during microscopic examination of the graptolite assemblages. All are preserved as external moulds and were studied by examination of latex casts. The interval covered by the conodont collections is less than that for the graptolites, from $1.2 \mathrm{~m}$ below CO15 (within the upper spiralis Biozone) to CO16/17 (within the lower murchisoni Biozone).

All figured specimens are housed in the Museo Geominero of the Spanish Geological Survey (IGME), Madrid (numbers prefixed MGM).

\section{Graptolite biostratigraphy}

Figure 2 is a range chart showing the stratigraphical ranges of all identified graptolites from the section. Most of the species encountered (including all those 


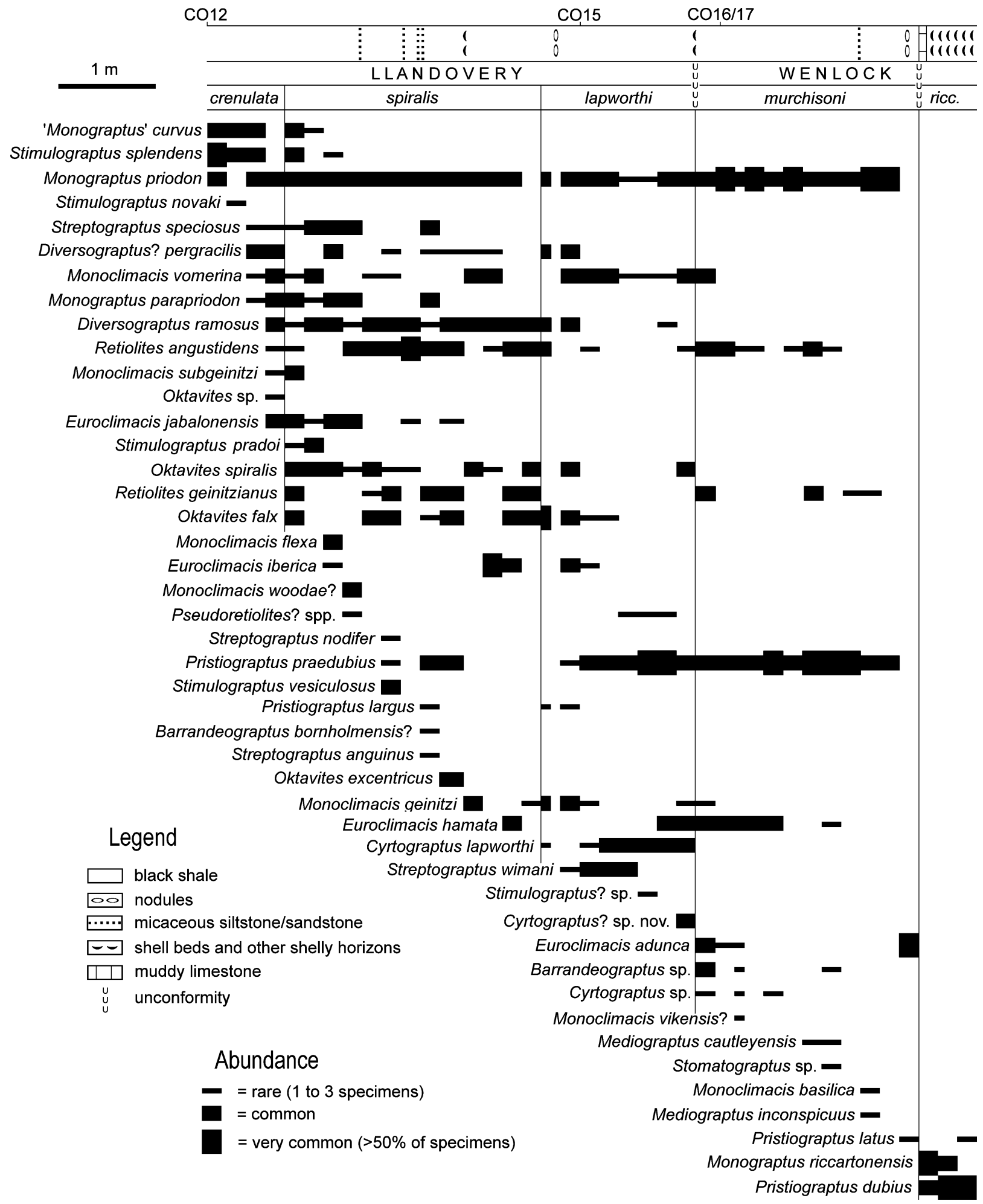

Figure 2. Log of the upper Telychian-lower Sheinwoodian strata of the Jabalón River section, with stratigraphical ranges of graptolites. CO12, CO15 and CO16/17 refer to marker levels painted onto the section. Horizon CO12 is $16.8 \mathrm{~m}$ above the base of the Guadarranquejo Formation.

of biostratigraphical significance) are illustrated in Figures 4-6.

The studied section commenced in the upper part of the crenulata (= tullbergi) Biozone. The lowest samples yielded low diversity graptolite assemblages (only three species present, despite the lithology being a black shale) with abundant Stimulograptus splendens
Š torch (Fig. 4c), 'Monograptus' curvus Manck (Fig. 4a) \pm M. priodon (Bronn) (Fig. 4v). A single specimen of Stimulograptus novaki (Bouček) (Fig. 4s) was also encountered. ' $M$.' curvus has long been recognized as occurring in the upper crenulata Biozone (Bouček, 1953). Its range extends into the spiralis Biozone in Germany (Schauer, 1971) and in the Jabalón 

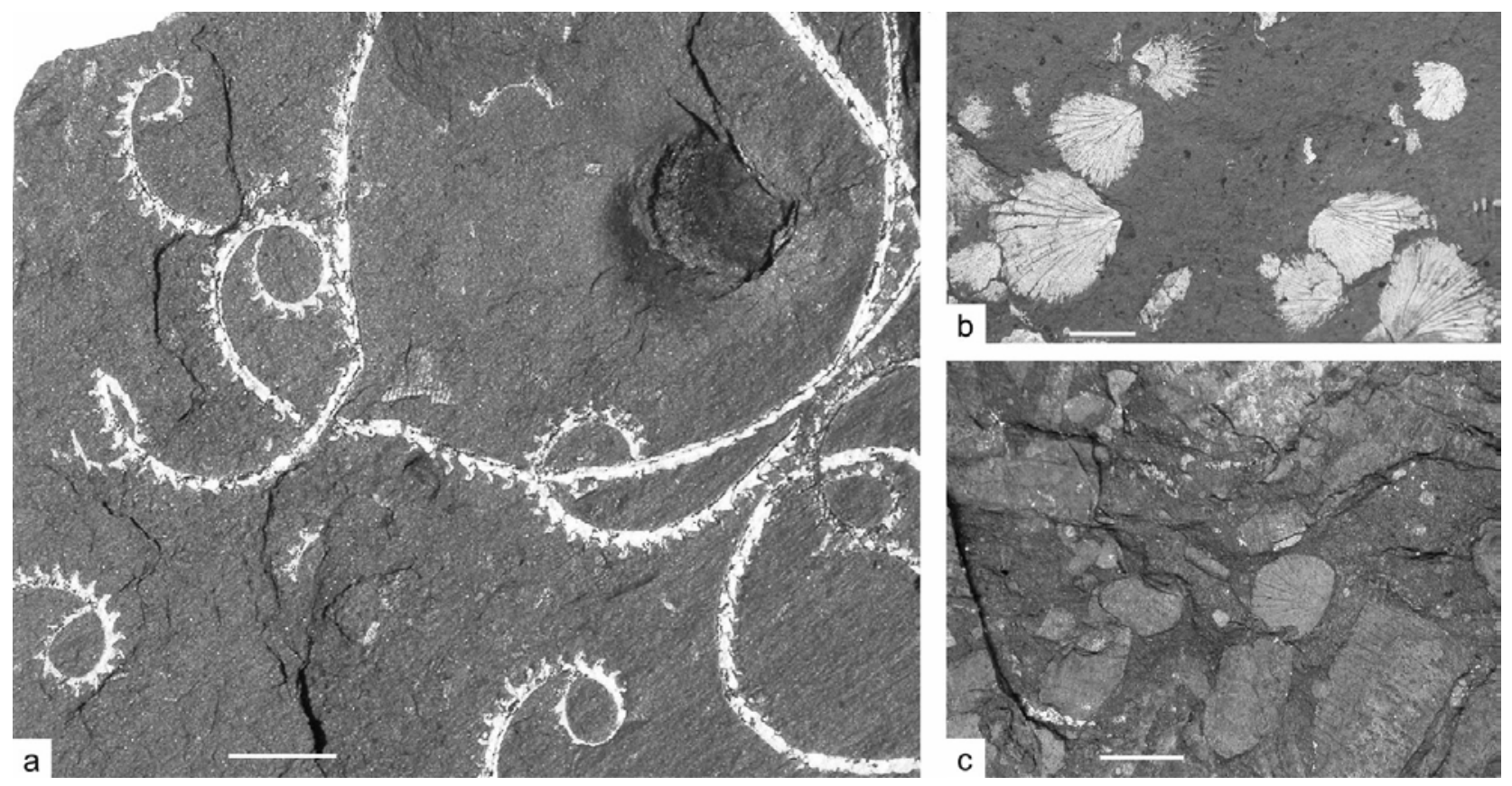

Figure 3. (a) MGM-134-S; slab bearing several Oktavites excentricus (Bjerreskov), CO12 + 2.4-2.65 m, middle spiralis Biozone; the graptolite periderm is coated with a white clay mineral. (b) MGM-135-S; shell-bearing shale typical of the highest Sheinwoodian beds sampled, CO16/17 + 2.4-2.6 m, riccartonensis or dubius Biozone. (c) MGM-136-S; shell bed marking the unconformity at the Llandovery/Wenlock boundary, CO15+1.2 m. Scale bars represent $5 \mathrm{~mm}$.

River section. Štorch (1998, p. 126) noted that St. splendens is both widespread and common in the upper tullbergi and lower spiralis biozones of the Iberian peninsula. With the exception of the cosmopolitan and stratigraphically very long-ranging $M$. priodon, none of the species identified has been recorded from outside of peri-Gondwanan Europe. Whether this reflects a restricted original distribution is uncertain, as the crenulata/spiralis Biozone transition is represented by non-graptolitic strata in many sections outside of periGondwanan Europe; for example, in the Aizpute-41 section, Latvia, red-beds occur at this level (Loydell, Männik \& Nestor, 2003, fig. 11).

As the crenulata/spiralis Biozone boundary is approached, diversity increases and the highest diversity in the section (14 species, three of which are new) is recorded at the base of the spiralis Biozone. With the exception of Streptograptus speciosus (Tullberg) (Fig. 4k), Streptograptus is rare in the spiralis Biozone. Some species (e.g. Mcl. flexa sp. nov. (Fig. 5c, d, $\mathrm{n}-\mathrm{p}$ ), Stimulograptus vesiculosus (Perner) (Fig. 4d) and Oktavites excentricus (Bjerreskov) (Figs 3a, 6a))

Figure 4. Graptolites from the Jabalón River section. (a) 'Monograptus' curvus Manck; MGM-137-S; CO12 + 0.4-0.6 m, upper crenulata Biozone. (b) Oktavites falx (Suess); MGM-138-S; CO15-0.4-0.6 m, upper spiralis Biozone. (c) Stimulograptus splendens Š torch; MGM-139-S; CO12 + 0.4-0.6 m, upper crenulata Biozone. (d) Stimulograptus vesiculosus (Perner); MGM140-S; CO12 + 1.8-2.0 m, middle spiralis Biozone. (e, h, i, o, y) Oktavites spiralis (Geinitz); (e) MGM-141-S; specimen with protracted proximal region; CO15-1.0-1.2 m, upper spiralis Biozone; $(\mathrm{h})$ MGM-144-S; specimen from immediately below shell bed marking Llandovery/Wenlock boundary; CO15 + 1.19 m, lapworthi Biozone; (i) MGM-145-S; specimen with shorter proximal region; CO15 to -0.2 m, lapworthi Biozone; (o) MGM-151-S; CO12 + 1.0-1.2 m, lower spiralis Biozone; (y) MGM-161-S; CO151.0-1.2 m, upper spiralis Biozone. (f) Streptograptus wimani (Bouček); MGM-142-S; CO15 + 0.4-0.6 m, lapworthi Biozone. (g) Stimulograptus? sp.; MGM-143-S; CO15 + 0.6-0.8 m, lapworthi Biozone. (j) Diversograptus ramosus Manck; MGM-146-S; CO151.0-1.2 m, upper spiralis Biozone. (k) Streptograptus speciosus (Tullberg); MGM-147-S; CO12 + 0.4-0.6 m, upper crenulata Biozone. (l) Diversograptus? pergracilis (Bouček); MGM-148-S; CO12 + 0.4-0.6 m, upper crenulata Biozone. (m) Monoclimacis vomerina (Nicholson); MGM-149-S; CO15-1.0-1.2 m, upper spiralis Biozone. (n) Monoclimacis subgeinitzi Fu; MGM-150-S; CO12 + 0.60.8 m, upper crenulata Biozone. (p) Oktavites sp.; MGM-152-S; CO12 + 0.6-0.8 m, upper crenulata Biozone. (q) Pseudoretiolites? sp.; MGM-153-S; CO12 + 1.4-1.6 m, lower spiralis Biozone. (r) Pristiograptus largus (Perner); MGM-154-S; CO15 to -0.2 m, lower lapworthi Biozone. (s) Stimulograptus novaki (Bouček); MGM-155-S; CO12 + 0.2-0.4 m, upper crenulata Biozone. (t) Monograptus parapriodon Bouček; MGM-156-S; CO12 + 0.6-0.8 m, upper crenulata Biozone. (u) Barrandeograptus sp.; MGM-157S; CO16/17-0.2-0.3 m, murchisoni Biozone. (v) Monograptus priodon (Bronn); MGM-158-S; CO12 + 0.4-0.6 m, upper crenulata Biozone. (w) Pristiograptus praedubius (Bouček); MGM-159-S; CO15 + 1.0-1.2 m, lapworthi Biozone. (x) Monoclimacis vikensis Bassett \& Rickards?; MGM-160-S; CO16/17 to + 0.2 m, murchisoni Biozone. (z) Streptograptus nodifer (Törnquist); MGM-162S; CO12 + 1.8-2.0 m, middle spiralis Biozone. (aa) Euroclimacis adunca (Bouček); MGM-163-S; CO15 + 1.2-1.4 m, murchisoni Biozone. 


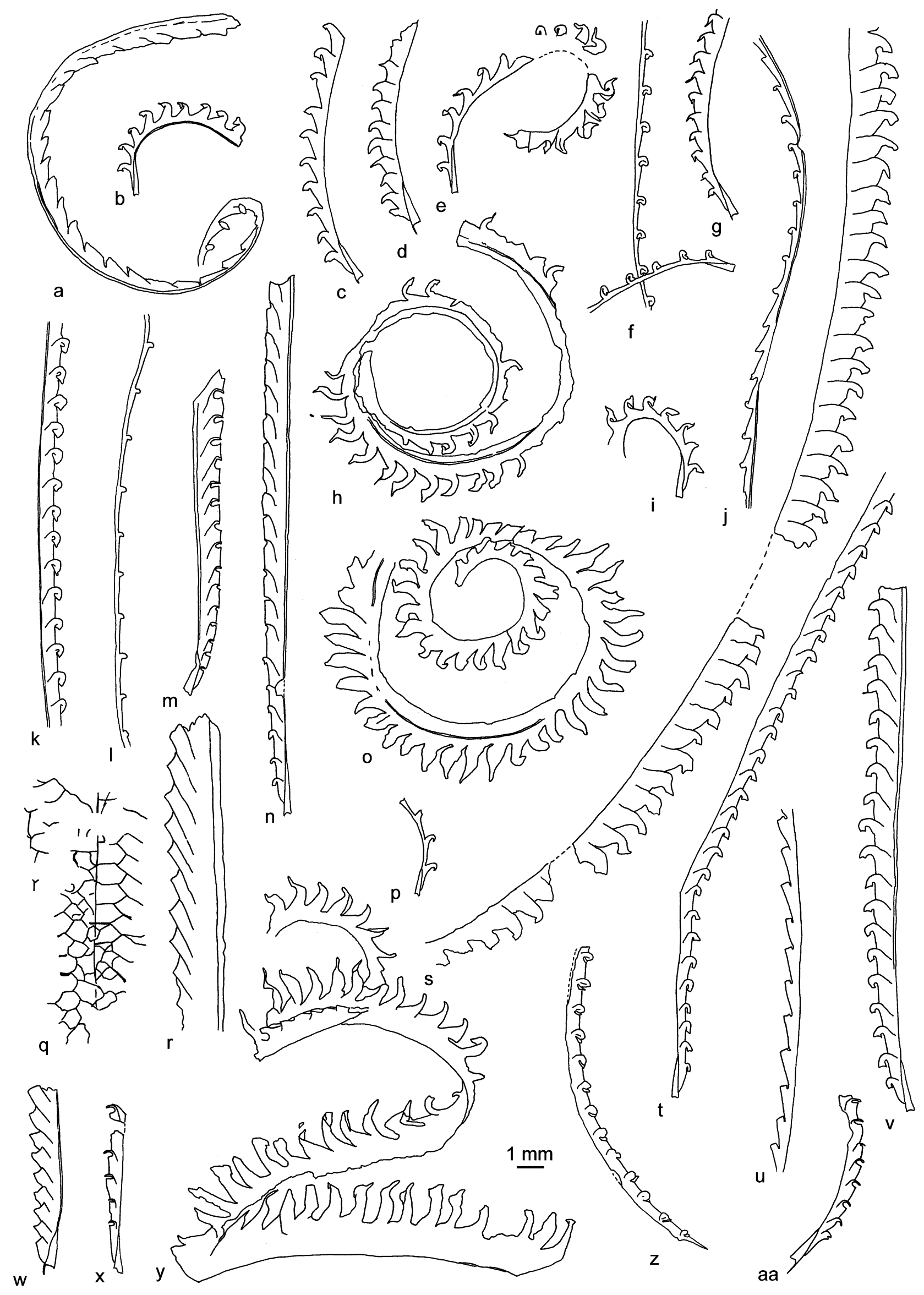

Figure 4. For legend see facing page. 

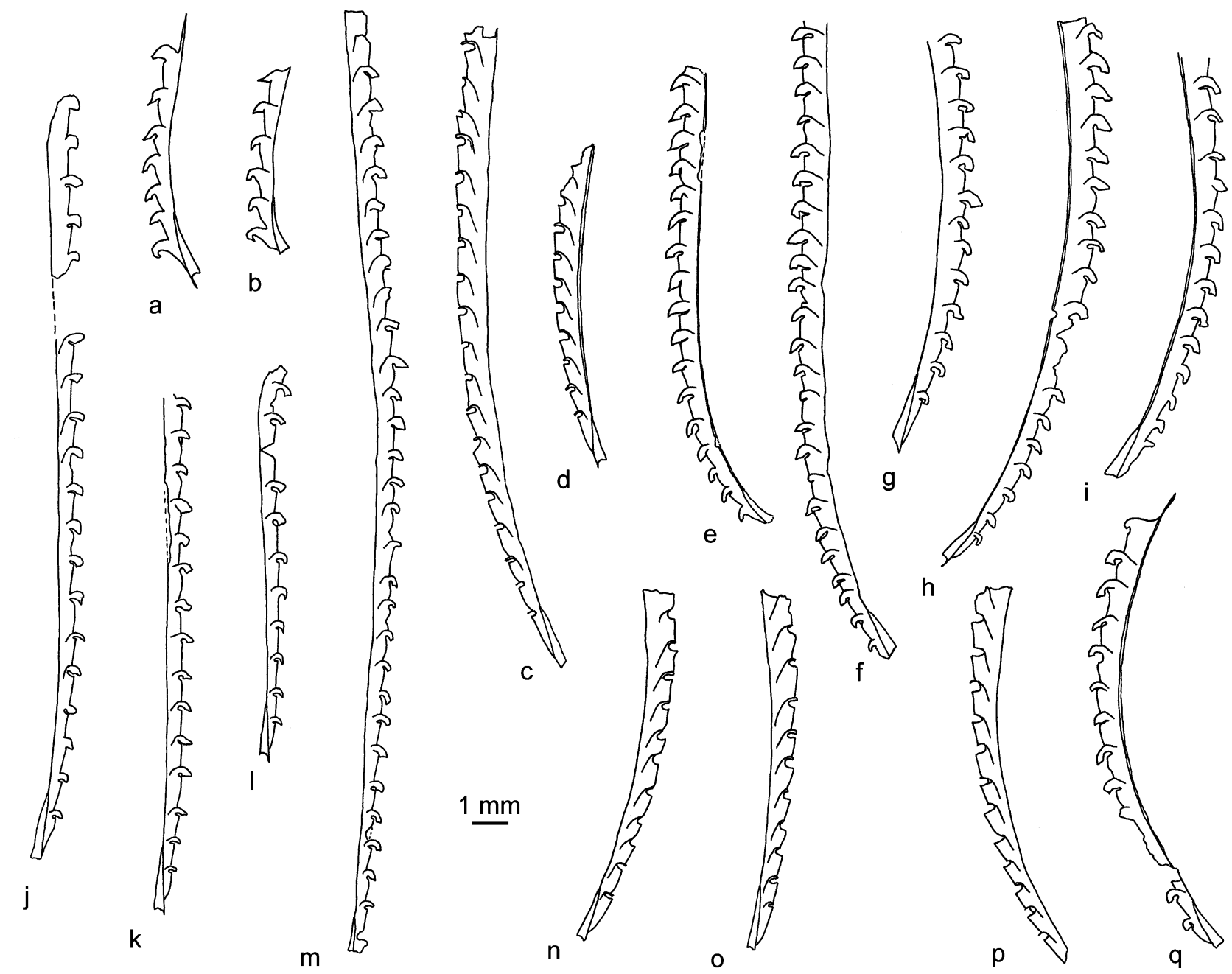

Figure 5. New graptolite species from the Jabalón River section. (a, b) Stimulograptus pradoi sp. nov.; lower spiralis Biozone; (a) MGM-164-S; CO12 + 0.8-1.0 m; (b) holotype, MGM-165-S; CO12 + 1.0-1.2 m. (c, d, n-p) Monoclimacis flexa sp. nov.; CO12 + 1.21.4 m, lower spiralis Biozone. (c) MGM-166-S; (d) MGM-167-S; (n) holotype, MGM-177-S; (o) MGM-178-S; (p) MGM-179-S. (e-i, q) Euroclimacis hamata sp. nov. (e) holotype, MGM-168-S; CO15 + 0.8-1.0 m, lapworthi Biozone; (f) MGM-169-S; CO16/17 to -0.2 m, murchisoni Biozone; (g) MGM-170-S; CO16/17 -0.2-0.4 m, lapworthi Biozone or murchisoni Biozone; (h) MGM-171-S; CO16/17 to -0.2-0.4 m, lapworthi Biozone or murchisoni Biozone; (i) MGM-172-S; CO15-0.6-0.8 m, upper spiralis Biozone; (q) MGM-180-S; CO16/17 to -0.2-0.4 m, lapworthi Biozone or murchisoni Biozone. (j-m) Euroclimacis jabalonensis sp. nov., CO12 + 0.6-0.8 m, upper crenulata Biozone. (j) holotype, MGM-173-S; (k) MGM-174-S; (l) MGM-175-S; (m) MGM-176-S.

are abundant, but occur in one sample only. Streptograptus nodifer (Törnquist) (Fig. 4z), and S. anguinus (Bouček) (Fig. 6k) occur within the middle part of the spiralis Biozone, which is consistent with previous records of these species (e.g. Loydell \& Cave, 1993). Stimulograptus vesiculosus (Perner) has previously been taken to indicate the upper part of the spiralis Biozone (e.g. by Loydell \& Cave, 1996; Loydell, Männik \& Nestor, 2003), but in sections with several metres of strata overlying the $S$. vesiculosus-bearing horizon that were either non-graptolitic or yielded nondiagnostic assemblages. The most abundant species of the upper spiralis Biozone in the Jabalón River section is Euroclimacis iberica Štorch (Fig. 6e), a species recorded only from Spain ( $\breve{S}$ torch, 1998). Some stratigraphical variation is seen within Oktavites spiralis (Geinitz) (Fig. 4e, h, i, o, y): those specimens from the top $0.8 \mathrm{~m}$ of the spiralis Biozone (e.g. Fig. 4e) have a longer proximal portion than specimens from lower in the biozone and from the lapworthi Biozone (e.g. Fig. 4i). Bjerreskov (1975, p. 72) noted the absence of $O$. spiralis from the middle of the spiralis Biozone on Bornholm, where it was replaced by O. excentricus. A similar stratigraphical relationship is exhibited by the Jabalón River section.

The lower (but not lowermost) part of the lapworthi Biozone yielded abundant Streptograptus wimani (Bouček) (Fig. 4f), a species recorded from a similar stratigraphical level in Wales (Loydell \& Cave, 1996) and Bohemia (Š torch, 1994a, fig. 3). Cyrtograptus lapworthi Tullberg (Fig. 6h) is rare in the lowermost part of the lapworthi Biozone, but increases in abundance at higher levels within the biozone. The presence of $O$. spiralis (Fig. 4h) immediately below the shell bed marking the Llandovery/Wenlock boundary (Fig. 3c) indicates that the Llandovery part of the Jabalón River section terminates below the top of the lapworthi Biozone. The long-ranging Euroclimacis 


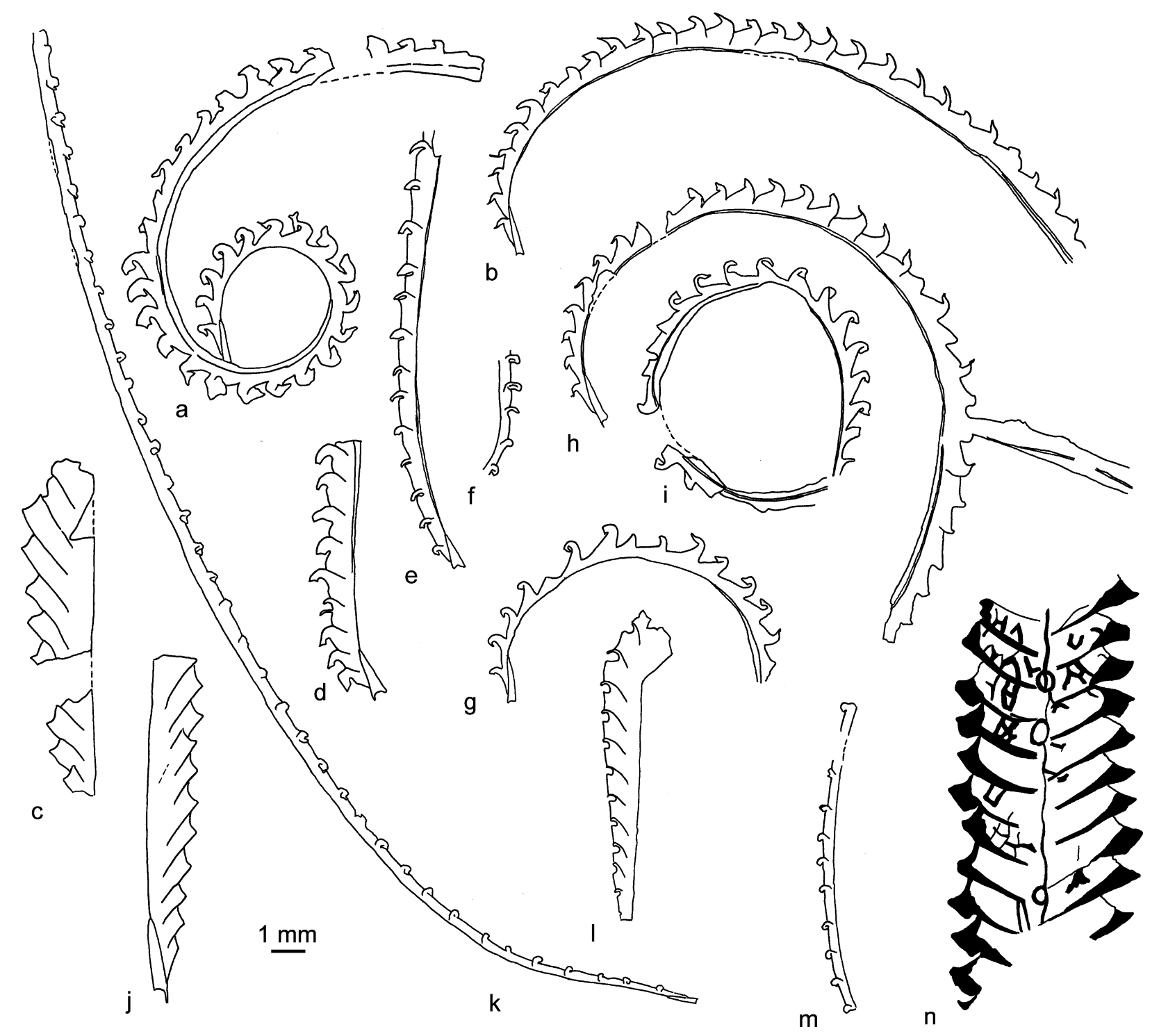

Figure 6. Graptolites from the Jabalón River section. (a) Oktavites excentricus (Bjerreskov); MGM-181-S; CO12 + $2.4-2.65$ m, middle spiralis Biozone. (b) Cyrtograptus sp.; MGM-182-S; CO16/17 to $-0.2 \mathrm{~m}$, murchisoni Biozone. (c) Pristiograptus latus (Bouček); MGM-183-S; CO16/17 + 2.4-2.6 m, riccartonensis Biozone or dubius Biozone. (d) Monograptus riccartonensis Lapworth; MGM184-S; CO16/17 + 2.0-2.2 m, riccartonensis Biozone. (e) Euroclimacis iberica Štorch; MGM-185-S; CO15-0.8-1.0 m, upper spiralis Biozone. (f) Mediograptus inconspicuus (Bouček); MGM-186-S; CO16/17 + 1.4-1.6 m, murchisoni Biozone. (g, i) Cyrtograptus? sp. nov.; CO16/17-0.3-0.4 m, lapworthi Biozone. (g) MGM-187-S; (i) MGM-189-S; (h) Cyrtograptus lapworthi Tullberg; MGM-188S; CO15 + 0.8-1.0 m, lapworthi Biozone. (j) Pristiograptus dubius (Suess); MGM-190-S; CO16/17 + 2.2-2.4 m, riccartonensis Biozone. (k) Streptograptus anguinus (Bouček); MGM-191-S; CO12 + 2.2-2.4 m, middle spiralis Biozone. (l) Monoclimacis basilica (Lapworth); MGM-192-S; CO16/17 + 1.4-1.6 m, murchisoni Biozone. (m) Mediograptus cautleyensis (Rickards); MGM-193-S; CO16/17 + 1.0-1.2 m, murchisoni Biozone. (n) Stomatograptus sp.; MGM-194-S; CO16/17 + 1.0-1.2 m, murchisoni Biozone.

hamata sp. nov. (Fig. 5e-i, q) is abundant in the higher lapworthi Biozone samples and is joined in the last sample below the Llandovery/Wenlock boundary shell bed by Cyrtograptus? sp. nov. (Fig. 6g, i). Both species have been recorded previously only from Morocco (Lüning et al. 2000), the former as E. sp. nov. from the lapworthi Biozone, the latter as $C$. sp. nov., from the centrifugus Biozone. Pristiograptus praedubius (Bouček) (Fig. 4w) increases dramatically in abundance through the lapworthi Biozone.

The upper lapworthi, insectus and centrifugus biozones are not present in the section; there is an unconformity between the middle lapworthi Biozone and the murchisoni Biozone, marked by a thin shell bed (Fig. 3c).

The murchisoni Biozone contains only rare specimens of Cyrtograptus, but it can be identified by the presence of Euroclimacis adunca (Bouček) (Fig. 4a), a species characteristic of this biozone ( $\breve{S}$ torch, 1994b, fig. 3; Loydell \& Cave, 1996). Assemblages throughout the biozone are dominated by Pristiograptus praedubius and Monograptus priodon. The abundance of $P$. praedubius in both the upper Telychian and lower Sheinwoodian strata is unique to the Jabalón River section; in other sections through strata of this age Pristiograptus is uncommon. Euroclimacis 
hamata sp. nov. is common in the lower part of the murchisoni Biozone. Mediograptus and Monoclimacis species are rare throughout the biozone. Retiolites is sporadically abundant. Overall graptolite diversity declines (to two species) towards the top of the biozone and the highest sample is characterized by a mass occurrence of E. adunca. Monograptus firmus Bouček has not been recorded from the section, and this, combined with the abrupt appearance of Monograptus riccartonensis Lapworth (Fig. 6d) immediately above the E. adunca mass occurrence level, is taken to indicate the presence of a second unconformity in the section. This unconformity is marked also by a lithological change: a muddy limestone of variable thickness (up to $0.3 \mathrm{~m}$ ) with a sharp erosive base overlies the E. aduncabearing black shales.

Although the upper part of the section studied continues to be graptolitic, shelly fossils dominate at this level (e.g. Fig. 3b). Diversity remains very low, with $M$. riccartonensis co-occurring with Pristiograptus dubius (Suess) (Fig. 6j). The highest sample contains only Pristiograptus. All three of these samples are assigned to the riccartonensis Biozone, although it is possible that the highest sample should be placed in the dubius Biozone, recognized at a similar level in, for example, Bohemia (Storch, 1994a, fig. 4) and Estonia (Loydell, Kaljo \& Männik, 1998, p. 777).

\section{Conodonts from the Jabalón River section}

Of the 145 conodont elements recognized in the 17 samples to yield them, 86 were identifiable at least to generic level. Only one sample yielded no conodonts at all; this was immediately below the shell bed marking the Llandovery/Wenlock boundary. As this horizon was represented by the largest sample examined for graptolites, the absence of conodonts may reflect taphonomic loss at this level. The highest number of conodont elements recognized from any one sample was 31, from the lower part of the lapworthi graptolite Biozone. The occurrence of conodonts in the Jabalón River section is shown in Figure 7.

The size of conodont elements is very variable, even on a single slab; of two ramiform elements from the uppermost spiralis graptolite Biozone, one is ten times larger than the other. This suggests that hydrodynamic sorting of conodont elements was minimal or absent, although some post-mortem dissociation of apparat-

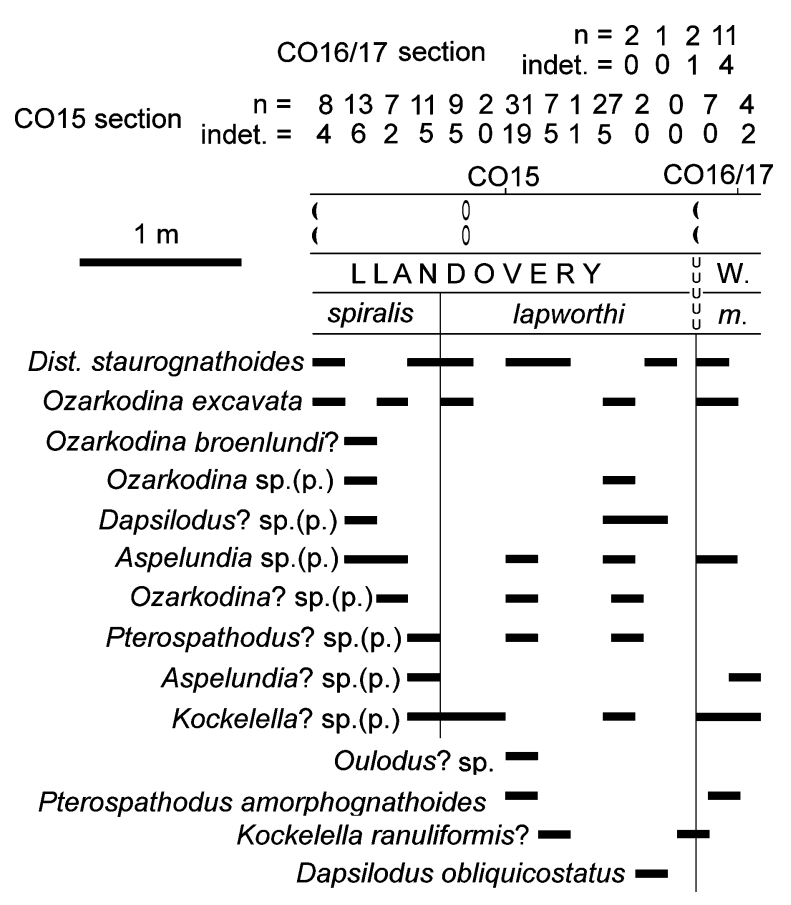

Figure 7. Distribution of conodonts through the upper spiralislower murchisoni graptolite biozones of the Jabalón River section.

uses must have taken place, perhaps during decay or as a result of scavenging. Morphologically, ramiform elements are the most abundant in all but one sample $(\mathrm{CO} 15+0.8-1.0 \mathrm{~m})$, in which only coniform elements were found. Otherwise coniform elements occur only sporadically and in low numbers.

Ozarkodina is the most common genus in the collections, having been confidently identified in eight samples. Distomodus elements occur in seven samples and Aspelundia in six. Other genera are either questionably identified or occur in small numbers in one or only a few samples. Unfortunately, from a biostratigraphical viewpoint, only two specimens could be assigned confidently to Pterospathodus: an Sb element from the lower lapworthi Biozone and a $\mathrm{Pa}$ element from the lower murchisoni graptolite Biozone (Fig. 8k), both of Pt. amorphognathoides Walliser. By comparison with the Aizpute-41 core (Loydell, Männik \& Nestor, 2003), these two occurrences lie towards the lower and upper ends of the stratigraphical range of Pt. amorphognathoides (marking the boundaries of the Pt. amorphognathoides Zonal Group of Jeppsson,

Figure 8. Conodonts from the upper spiralis-lower murchisoni graptolite biozones of the Jabalón River section. (a, b, g, i, j, l, n, o) Ozarkodina excavata (Branson \& Mehl); (a) CO/S2733; Sa? element, posterior view; CO15-1.0-1.2 m; (b) CO/S2743; Sa? element, anterior view; CO15-0.4-0.6 m; (g) CO/S2755; Sc element, inner lateral view; CO15 to -0.2 m; (i) CO/S2749; Sc element, inner lateral view; CO15-0.8-1.0 m; (j) CO/S2751; P element, lateral view; CO15-0.6-0.8 m; (l) CO/S2748; Sc element, inner lateral view; CO15-0.8-1.0 m; (n) CO/S2746; P element, lateral view; CO15-0.2-0.4 m; (o) CO/S2737; P element, lateral view; CO15-1.21.4 m. (c-f, h) Distomodus staurognathoides (Walliser); (c) CO/S2732; Pa element, upper view; CO15-1.0-1.2 m; (d) CO/S2731; Pa element, oblique upper view; CO15-0.4-0.6 m; (e) CO/S2110; S element, lateral view; CO15-0.4-0.6 m; (f) CO/S2747; S element, lateral view; CO116/17-0.2-0.4 m; (h) CO/S2757; S element, lateral view; CO15-0.4-0.6 m. (k) Pterospathodus amorphognathoides Walliser; CO/S2745; Pa element, upper oblique view; CO16/17 to $-0.2 \mathrm{~m}$. (m) Dapsilodus obliquicostatus (Branson \& Mehl); CO/S2790; lateral view; CO15 + 0.8-1.0 m. Scale bars represent $100 \mu \mathrm{m}$. 

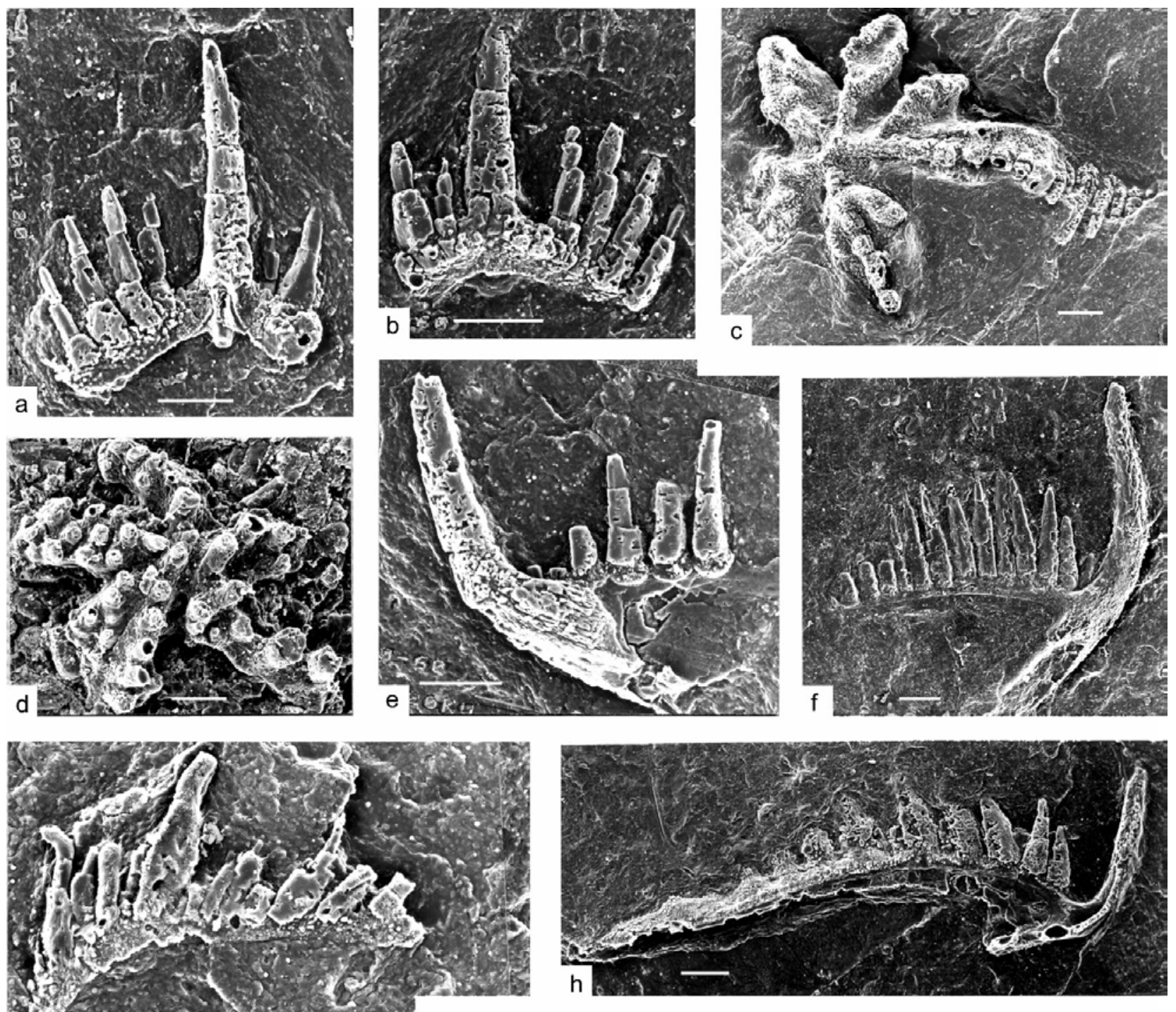

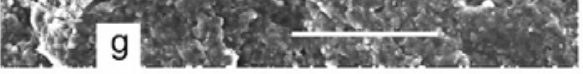
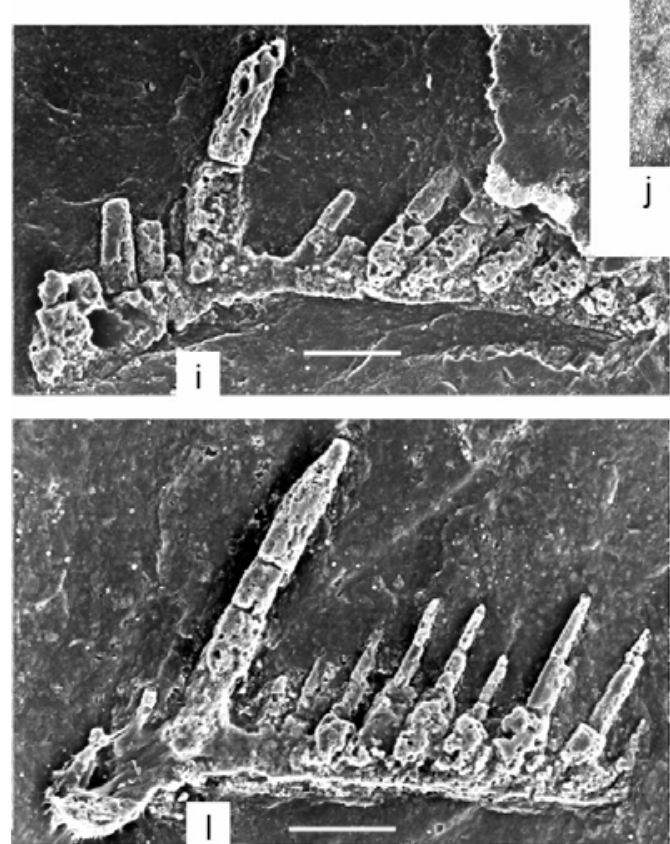
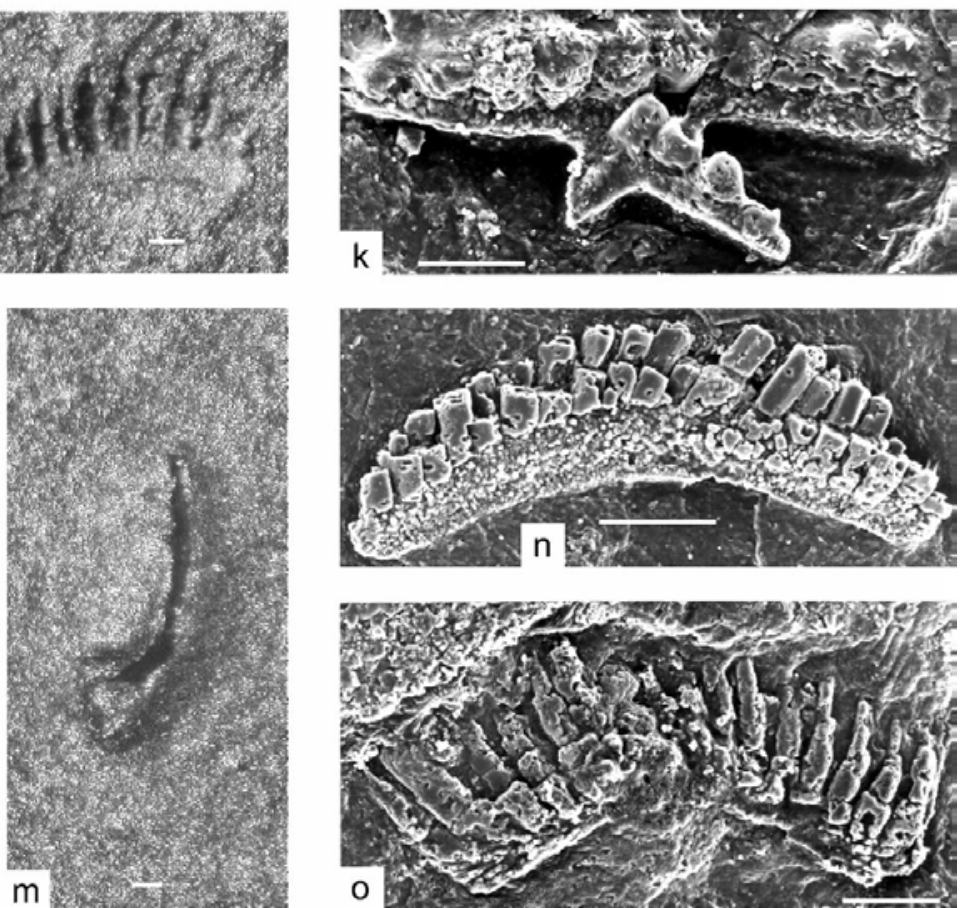

Figure 8. For legend see facing page. 


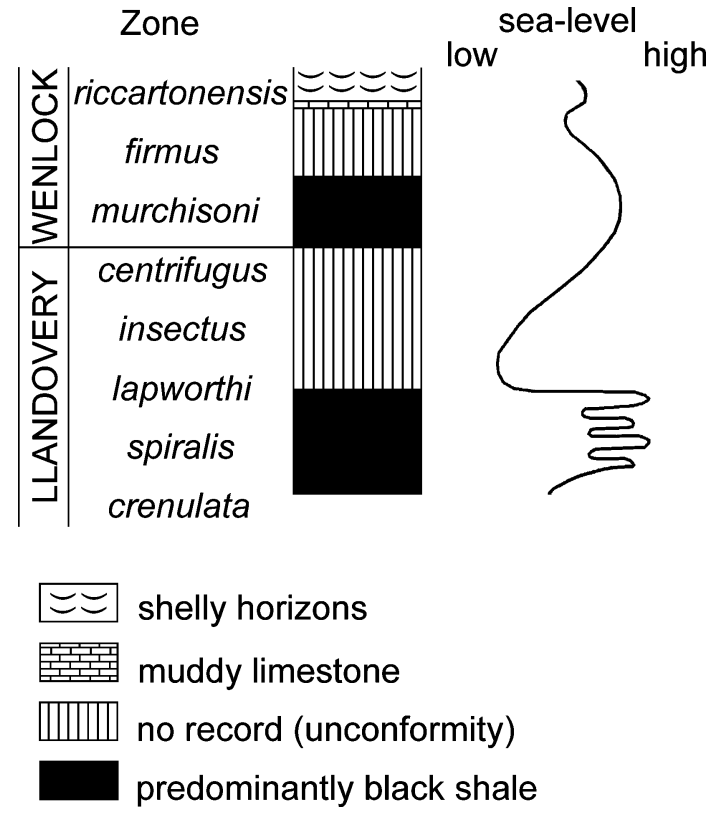

Figure 9. Summary stratigraphy of the Jabalón River section compared with Loydell's (1998) eustatic sea-level curve for the late Telychian-early Sheinwoodian. Note that the shell bed sandwiched between the Telychian and Sheinwoodian graptolitic shales is not shown as it is not known whether it is of Telychian or Sheinwoodian age.

1997). The other three species confidently identified to species level, Ozarkodina excavata (Branson \& Mehl) (Fig. 8a, b, g, i, j, l, n, o), Distomodus staurognathoides (Walliser) (Fig. 8c-f, h) and Dapsilodus obliquicostatus (Branson \& Mehl) (Fig. 8m), are all long-ranging species (Armstrong, 1990; Jeppsson, 1997; Loydell, Männik \& Nestor, 2003; Zhang, Barnes \& Jowett, 2006) with ranges extending both below the spiralis graptolite Biozone and above the murchisoni Biozone.

\section{Discussion}

Figure 9 summarizes the upper Telychian-lower Sheinwoodian stratigraphy of the Jabalón River section and compares it with the eustatic sea-level curve of Loydell (1998). The rock record is dominated by black graptolitic shales deposited during intervals of rising or high sea-level (late crenulata through to middle lapworthi zones; murchisoni Zone), with muddy limestones and shell beds representing deposition during the riccartonensis Zone. The two unconformities in the section correspond with intervals of lowered sealevel, commencing in the late lapworthi Zone in the late Telychian and late murchisoni Zone in the early Sheinwoodian.

\section{Systematic palaeontology (DKL, PŠ, JCG-M)}

The following abbreviations are used below: DVW - dorsoventral width; 2TRD - two thecae repeat distance (Howe, 1983).
Table 1. Measurements (in mm) of proximal DVW and 2TRD in Euroclimacis jabalonensis sp. nov.

\begin{tabular}{lccccc}
\hline & th1 & th2 & th3 & th5 & \multicolumn{1}{c}{ th10 } \\
\hline DVW & $0.45-0.6$ & $0.45-0.55$ & $0.45-0.6$ & $0.55-0.65$ & $0.6-0.75$ \\
2TRD & & $1.5-2.05$ & $1.6-1.95$ & $1.55-2.15$ & $1.75-2.2$ \\
\hline
\end{tabular}

Euroclimacis jabalonensis sp. nov. Figure $5 j-m$

Name. After the Jabalón River.

Material. About 50 specimens, including 9 proximal ends, from the uppermost crenulata Biozone and lower and middle spiralis Biozone. The species is most abundant in the lower part of its stratigraphical range.

Holotype. Specimen MGM-173-S (Fig. 5j), from sample $\mathrm{CO} 12+0.6-0.8 \mathrm{~m}$, upper crenulata Biozone.

Diagnosis. Euroclimacis with straight or almost straight rhabdosome, increasing in DVW slowly from $0.45-0.6 \mathrm{~mm}$ at th1 to a distal maximum of $0.85 \mathrm{~mm}$. All thecae are hooded.

Description. The rhabdosome is straight or shows very slight dorsal flexure. The sicula is $1.4-1.75 \mathrm{~mm}$ long, with an apertural width of $0.3-0.35 \mathrm{~mm}$. It apex reaches between one-quarter and two-thirds up th2. The virgella is short and inconspicuous. Thecae have small apertural excavations; all have hoods. Ventral prothecal walls are inclined to the rhabdosome axis proximally; distally they are nearly parallel to it. Measurements of proximal DVW and 2TRD are given in Table 1; distal maxima are $0.85 \mathrm{~mm}$ and $2.2 \mathrm{~mm}$ respectively.

Remarks. Euroclimacis jabalonensis differs from other Euroclimacis species in its lack of conspicuous dorsal rhabdosome curvature and in its low and slowly increasing DVW. Poorly preserved fragments can be confused with Monograptus parapriodon, particularly when the aperture is obscured by the hood.

\section{Euroclimacis hamata sp. nov.}

Figure $5 \mathrm{e}-\mathrm{i}$, q

\section{Euroclimacis sp. nov.; Lüning et al., pl. 1, fig. M.}

Name. From the Latin, referring to the prominent metathecal hooks.

Material. Several hundred specimens, from the upper spiralis Biozone, upper lapworthi Biozone and lower to middle murchisoni Biozone.

Holotype. Specimen MGM-168-S (Fig. 5e), from 0.8-1.0 m above CO15, lapworthi Biozone.

Diagnosis. Euroclimacis with dorsal rhabdosome curvature proximally; rhabdosome is straight distally. Metathecae have prominent hoods throughout the rhabdosome. Maximum DVW is $1.4 \mathrm{~mm}$.

Description. The rhabdosome exhibits gentle dorsal curvature proximally and becomes straight distally. The sicula is $1.2-1.45 \mathrm{~mm}$ long, its apex usually reaching halfway up th2, but ranging from just above the top of th1 to just below the top of th2. The virgella is short and inconspicuous. Thecae throughout bear prominent hoods; 
Table 2. Measurements (in mm) of proximal DVW and 2TRD in Euroclimacis hamata sp. nov.

\begin{tabular}{lccccrc}
\hline & th1 & th2 & th3 & th5 & th10 & th15 \\
\hline DVW & $0.45-0.7$ & $0.5-0.7$ & $0.55-0.8$ & $0.6-0.85$ & $0.8-1.05$ & $0.95-1.15$ \\
2TRD & & $1.3-1.8$ & $1.3-1.8$ & $1.35-2.0$ & $1.55-2.05$ & $1.4-1.7$ \\
\hline
\end{tabular}

Table 3. Measurements (in mm) of proximal DVW and 2TRD in Monoclimacis flexa sp. nov.

\begin{tabular}{lcccccr}
\hline & th1 & th2 & th3 & th5 & th10 & th15 \\
\hline DVW & $0.4-0.45$ & $0.45-0.55$ & $0.5-0.6$ & $0.6-0.75$ & $0.75-1.0$ & $0.9-1.05$ \\
2TRD & & $1.3-1.7$ & $1.3-1.7$ & $1.4-1.7$ & $1.5-1.85$ & $1.6-1.85$ \\
\hline
\end{tabular}

these often obscure the apertural excavation giving the thecae a simply hooked Monograptus- or Stimulograptus-like appearance. Measurements of proximal DVW and 2TRD are given in Table 2; distally, DVW is $1.0-1.4 \mathrm{~mm}$; 2TRD is $1.75-2.0 \mathrm{~mm}$. DVW is strongly influenced by the orientation of the rhabdosome: the thecal hoods may become accentuated or partially obscured by flattening of rhabdosomes that are very slightly oblique to bedding.

Remarks. Euroclimacis hamata differs from E. iberica Štorch, 1998 and E. adunca (Bouček) (see Štorch, 1994b for description) in having more prominent thecal hoods, in lacking ventral rhabdosome curvature distally and in attaining a greater distal DVW. E. radotinensis (Bouček) is more strongly dorsally curved proximally than E. hamata and attains a lesser maximum DVW $(1.0 \mathrm{~mm})$. Euroclimacis hamata is a relatively long-ranging species occurring in the upper Telychian and lowermost Sheinwoodian.

\section{Monoclimacis flexa sp. nov.}

Figure 5c, d, n-p

Name. Referring to the dorsal rhabdosome curvature.

Material. 59 specimens, including 14 proximal ends; from one sample only $(\mathrm{CO} 12+1.2-1.4 \mathrm{~m})$ in the lower spiralis Biozone.

\section{Holotype. Specimen MGM-177-S (Fig. 5n).}

Diagnosis. Monoclimacis exhibiting gentle dorsal rhabdosome curvature, which is most pronounced proximally. DVW increases from $0.4-0.45 \mathrm{~mm}$ at th1 to a distal maximum of $1.15 \mathrm{~mm}$.

Description. The rhabdosome is dorsally curved. The amount of curvature proximally is variable (compare Fig. 50 with Fig. $5 p$ ), and decreases distally so that distal fragments are almost straight. Thecae are of typical monoclimacid form, although with the free ventral wall gently inclined rather than parallel to the rhabdosome axis. The sicula is $1.3-1.6 \mathrm{~mm}$ long, with an apertural width of $0.25-0.35 \mathrm{~mm}$. Its apex usually reaches to the aperture of th1, but occasionally reaches a higher level, to the top of or just above the top of th1. The virgella is short and inconspicuous. Measurements of proximal DVW and 2TRD are given in Table 3. Distal maxima are $1.15 \mathrm{~mm}$ and $1.9 \mathrm{~mm}$, respectively.

Remarks. Monoclimacis flexa can be distinguished from previously described Llandovery Monoclimacis species by its dorsal curvature. It is most similar to the lower Wenlock Euroclimacis adunca (Bouček) (see Storch, 1994b for description), but differs in the lack of conspicuous apertural hoods in all specimens, in its less pronounced and more continuous dorsal rhabdosome curvature (this affects only the proximal end of E. adunca) and in being slightly
Table 4. Measurements (in mm) of proximal DVW and 2TRD in Stimulograptus pradoi sp. nov.

\begin{tabular}{lccrc}
\hline & th1 & th2 & th3 & \multicolumn{1}{c}{ th5 } \\
\hline DVW & $0.75-0.9$ & $0.65-0.8$ & $0.65-0.8$ & $0.7-0.8$ \\
2TRD & & $1.3-1.55$ & $1.5-1.7$ & $1.4-1.85$ \\
\hline
\end{tabular}

narrower proximally (DVW at th1 of E. adunca is 0.5$0.7 \mathrm{~mm})$.

Stimulograptus pradoi sp. nov.

Figure 5a, b

Name. After mining engineer Casiano de Prado y Vallo (1797-1866), the first author to identify Silurian graptolites in Spain and who discovered the Silurian strata at Corral de Calatrava.

Material. Seven specimens, from the lowest $0.4 \mathrm{~m}$ of the spiralis Biozone.

Holotype. Specimen MGM-165-S (Fig. 5b) from sample $\mathrm{CO} 12+1.0-1.2 \mathrm{~m}$, lower spiralis Biozone.

Diagnosis. Dorsally curved Stimulograptus with very prominent th1.

Description. Only proximal ends with up to 7 thecae are present in the collections. The rhabdosome is gently dorsally curved. The sicula is $1.6-1.85 \mathrm{~mm}$ long, its apex reaching between half-way up and the top of th2. The virgella is short and inconspicuous. The prothecal wall of th1 is at a high angle to the sicula and the DVW at th1 is greater than in other proximal thecae. The metatheca exhibits a pronounced hook, so that the aperture appears to face the ventral prothecal wall. From th2 onwards thecae are of typical stimulograptid form, lacking overlap, with hooked metathecae and prothecae at a low angle to the rhabdosome axis. Measurements of DVW and 2TRD are given in Table 4.

Remarks. Stimulograptus pradoi differs from St. splendens Štorch, 1998 primarily in its much more prominent th1. It also has slightly closer thecal spacing proximally (in St. splendens 2TRD is $1.7-1.9 \mathrm{~mm}$ at th2). Fragments lacking the proximal end would be very difficult to distinguish.

\section{Conclusions}

The Jabalón River section is not as complete stratigraphically as previously thought. Two significant unconformities occur, such that the upper lapworthi, insectus, centrifugus and firmus biozones are not 
represented in the section. Graptolites are extremely abundant; 45 species are recognized from upper Telychian-lower Sheinwoodian strata. Assemblages comprise a mixture of cosmopolitan species and those with a more restricted distribution (e.g. Euroclimacis iberica, E. hamata, Stimulograptus splendens) recorded previously only from peri-Gondwanan Europe or Morocco. The composition of graptolite assemblages at some levels differs from that previously recorded from equivalent stratigraphical levels elsewhere, particularly in the high relative abundance of Pristiograptus praedubius and of Euroclimacis. The occurrences of the conodont Pterospathodus amorphognathoides (indicating the amorphognathoides Zonal Group) are within its recorded stratigraphical range (within the graptolite biozonation) elsewhere. The stratigraphical record of the Jabalón River section is consistent with the eustatic sea-level curve for the early Silurian of Loydell (1998).

Acknowledgements. Wendy Johnson and Zuzana Štorchova assisted in sample collection. GNS thanks Peep Männik for comments on conodont identifications.

\section{References}

ARMSTRONG, H. A. 1990. Conodonts from the Upper Ordovician-Lower Silurian carbonate platform of North Greenland. Grønlands Geologiske Undersøgelse Bulletin 159, 1-151.

BJERRESKOV, M. 1975. Llandoverian and Wenlockian graptolites from Bornholm. Fossils and Strata 8, 1-94.

BOUČEK, B. 1953. Biostratigraphy, development and correlation of the Želkovice and Motol Beds of the Silurian of Bohemia. Sborník Ústředního Ústavu Geologického 20, 473-84.

CORTÁZAR, D. 1880. Reseña física y geológica de la provincia de Ciudad Real. Boletín de la Comisión del Mapa Geológico de España 7, 289-330.

García Palacios, A., GuTiÉrRez-Marco, J. C. \& HerRANZ ARAÚJO, P. 1996. Edad y correlación de la «Cuarcita de Criadero» y otras unidades cuarcíticas del límite Ordovícico- Silúrico en la Zona Centroibérica meridional (España y Portugal). Geogaceta 20, 19-22.

GARCíA PALACIOS, A. \& RÁBANO, I. 1996. Hallazgo de trilobites en pizarras negras graptolíticas del Silúrico inferior (Telychiense, Llandovery) de la Zona Centroibérica (España). Geogaceta 20, 239-41.

HowE, M. P. A. 1983. Measurement of thecal spacing in graptolites. Geological Magazine 120, 635-8.

JEPPSSON, L. 1997. A new latest Telychian, Sheinwoodian and early Homerian (early Silurian) standard conodont zonation. Transactions of the Royal Society of Edinburgh: Earth Sciences 88, 91-114.

LOYDELL, D. K. 1998. Early Silurian sea-level changes. Geological Magazine 135, 447-71.

Loydell, D. K. \& CAVE, R. 1993. The Telychian (Upper Llandovery) stratigraphy of Buttington Brick Pit, Wales. Newsletters on Stratigraphy 29, 91-103.
LOYDELL, D. K. \& CAVE, R. 1996. The Llandovery-Wenlock boundary and related stratigraphy in eastern mid-Wales with special reference to the Banwy River section. Newsletters on Stratigraphy 34, 39-64.

LOYDELL, D. K., KALJO, D. \& MÄNNIK, P. 1998. Integrated biostratigraphy of the lower Silurian of the Ohesaare core, Saaremaa, Estonia. Geological Magazine 135, 769-83.

LOYDELL, D. K., MÄNNIK, P. \& NESTOR, V. 2003. Integrated biostratigraphy of the lower Silurian of the Aizpute-41 core, Latvia. Geological Magazine 140, 205-29.

LÜ NING, S., LOYDELL, D. K., SUTClifFE, O., AIT SALEM, A., Zanella, E., Craig, J. \& Harper, D. A. T. 2000. Silurian-Lower Devonian black shales in Morocco: which are the organically richest horizons? Journal of Petroleum Geology 23, 293-311.

Portero García, J. M., Ancochea, E., Gallardo, J. \& PÉREZ-GonzÁ LEZ, A. 1988. Memoria Explicativa de la Hoja $n^{\circ} 784$ (Ciudad Real) del Mapa Geológico de España E. 1:50.000 (Segunda Serie). Madrid: Instituto Geológico y Minero de España, 101 pp.

Prado, C. de, Verneuil, E. de \& Barrande, J. 1855. Mémoire sur la Géologie d'Almaden, d'une partie de la Sierra Morena et des Montagnes de Tolède (C. de Prado), suivi d'une description des fossiles qui s'y rencontrent (E. de Verneuil et J. Barrande). Bulletin de la Société Géologique de France 12(2), 182-204, 9641025.

RoBARDET, M. \& GUTIÉRREZ-MARCO, J. C. 2002. Silurian. In The geology of Spain (eds W. Gibbons \& T. Moreno), pp. 51-66. London: Geological Society.

SARMIENTO, G. \& GARCía PALACIOS, A. 1996. Conodontos silúricos (Telychiense-Sheinwoodiense) en las facies sapropelíticas negras de Corral de Calatrava (Ciudad Real), España. In Comunicaciones XII Jornadas de Paleontología (eds T. Palacios \& R. Gozalo), pp. 10911. Badajoz.

SCHAUER, M. 1971. Biostratigraphie und Taxonomie der Graptolithen des tieferen Silurs unter besonderer Berücksichtigung der tektonischen Deformation. Freiberger Forschungshefte (C) Paläontologie 273, 1185.

Š TORCH, P. 1994a. Graptolite biostratigraphy of the Lower Silurian (Llandovery and Wenlock) of Bohemia. Geological Journal 29, 137-65.

ŠTORCH, P. 1994b. Llandovery-Wenlock boundary beds in the graptolite-rich sequence of the Barrandian area (Bohemia). Journal of the Czech Geological Society 39, 163-82.

ŠTORCH, P. 1998. New data on Telychian (Upper Llandovery, Silurian) graptolites from Spain. Journal of the Czech Geological Society 43, 113-41.

Štorch, P., GUTIÉRREZ-MARCO, J. C., SARMIENTO, G. N. \& RÁBANO, I. 1998. Upper Ordovician and Lower Silurian of Corral de Calatrava, southern part of the Central Iberian Zone. Temas Geológico-Mineros ITGE 23, 31925.

ZhANG, S., BARNES, C. R. \& JowetT, D. M. S. 2006. The paradox of the global standard Late OrdovicianEarly Silurian sea level curve: evidence from conodont community analysis from both Canadian Arctic and Appalachian margins. Palaeogeography, Palaeoclimatology, Palaeoecology 236, 246-71. 